\title{
EFFECT OF NITROGEN AND PHOSPHORUS ON THE GROWTH AND YIELD PERFORMANCE OF SOYBEAN
}

\section{Mst. Anjumanara Begum ${ }^{1}$, Md. Aminul Islam², Quazi Maruf Ahmed ${ }^{3}$, Md. $^{*}$ Anwarul Islam ${ }^{1}$ and Md. Moshiur Rahman ${ }^{1}$}

${ }^{1}$ Department of Agronomy, Bangladesh Agricultural University, Mymensingh-2202, Bangladesh; ${ }^{2}$ On Farm Research Division, Bangladesh Agricultural Research Institute, Pabna-6600, Bangladesh; ${ }^{3}$ Regional Horticultural Research Station, Bangladesh Agricultural Research Institute Narshingdi-1600, Bangladesh

*Corresponding author: Md. Aminul Islam; E-mail: amin_bau@yahoo.com

\section{ARTICLE INFO ABSTRACT}

Received

12.03.2015

Accepted

12.04.2015

Online

19.04.2015

Key words

Nitrogen

Phosphorus

Production

Soybean
The experiment was conducted at the Agronomy Field Laboratory of Bangladesh Agricultural University, Mymensingh to study the effects of nitrogen and phosphorus on the performance of soybean. Three levels of nitrogen $\left(0,25\right.$ and $\left.40 \mathrm{~kg} \mathrm{~N} \mathrm{ha}^{-1}\right)$ and four levels of phosphorus $\left(0,18,36\right.$ and $\left.54 \mathrm{~kg} \mathrm{P}^{\mathrm{P}} \mathrm{h}^{-1}\right)$ were considered as treatment for the experiment. Soybean responded remarkably to the added nitrogenous and phosphatic fertilizers as the crop characters were significantly influenced by different levels of nitrogen and phosphorus. Significant effect on number of branches and seeds plant ${ }^{-1}$, plant height, number of filled pods plant $^{-1}$, weight of seeds plant ${ }^{-1}$, dry weight of plant, stover weight plant ${ }^{-1}, 1000$-seed weight, seed and stover yield were obtained from the combined application of $25 \mathrm{~kg} \mathrm{~N}$ with $54 \mathrm{~kg} \mathrm{P}^{\mathrm{p}} \mathrm{h}^{-1}$.

To cite this article: MA Begum, MA Islam, QM Ahmed, MA Islam and MM Rahman. 2015. Effect of nitrogen and phosphorus on the growth and yield performance of soybean. Res. Agric. Livest. Fish. 2 (1): 35-42. 


\section{INTRODUCTION}

Soybean (Glycine max L. Merril) ranks first as an oilseed crop of the world. It has a tremendous value in agriculture as a good source of high quality plant protein and vegetable oils in one hand and nitrogen fixing ability on the other. It belongs to the family Leguminosae, sub family Papilionaceae. Soybean is quite wide spread in different regions of the world and grows well from the tropics to the temperate zones with greater production in the United States, Brazil, China, Mexico, Indonesia and Argentina. The world production of soybean as estimated in 2008 was 231.27 million ton from an area of 96.47 million hectares (FAO, 2009). For its nutritive value soybean has been called miracle golden bean, the golden nugget, the nugget of nutrition etc. soybean being a good source of protein, unsaturated fatty acids, minerals like $\mathrm{Ca}$ and $\mathrm{P}$ and vitamin $\mathrm{A}, \mathrm{B}, \mathrm{C}$ and D can meet up different nutritional needs of human being (USDA, 2009).

Prospects of soybean farming in Bangladesh is bright as it can successfully be grown under a wide range of climatic and edaphic conditions and cultivated throughout the year in Bangladesh (Rahman, 1982). Soybean helps to improve the soil by fixing the atmospheric nitrogen through Rhizobium bacteria. Steward (1966) observed that the soybean plants could fix $94 \mathrm{~kg}_{\text {nitrogen ha-1 in }}$ soil in a season. In Bangladesh the area under soybean cultivation is about 5000 ha with a production of 4000 ton \& the yield ranges from 1.50 to2.30 tha-1 (BARI, 2005). The lower yield of soybean at farmer's level is mainly attributed to the lack of improved agronomic management practices of which judicious fertilizer application is an important determinant for better yield of soybean.

Among the nutrients, nitrogen is a major essential plant nutrient element. It has the quickest and most pronounced effect on plant growth and yield of crops. It tends primarily to encourage above ground vegetative growth and to impart deep green colour to the leaves. In all plants, nitrogen governs a considerable degree of utilization of potassium, phosphorus and other nutrients. Plants receiving insufficient nitrogen are stunted in growth with restricted root systems. The leaves turn yellow or yellowish green and tend to drop off.

Phosphorus can play an important role in seed yield as it is one of the limiting plant nutrients for production of soybean (Rao et al., 1995). Its uptake and utilization by soybean is essential for ensuring proper growth \& improving yield and quality of the crop. It influences the growth of roots, helps uptake of more nutrients and nodule formation, balances the nitrogen deficiency in soil and assists in seed maturation. Thus, it is needed to find out proper amount of nitrogen and phosphorus required for achieving better yield of soybean. In view of the facts stated above, a field experiment was conducted to evaluate the effect of different levels of nitrogen and phosphorus and their interaction on the yield of soybean.

\section{MATERIALS AND METHODS}

The experiment was conducted at the Agronomy Field Laboratory, Bangladesh Agricultural University, Mymensingh during 5 January to 20 April, 2009 to study the effects of rate of nitrogen and phosphorus on the yield of soybean. The experimental field was a high land having sandy loam soil with $\mathrm{pH}$ 6.9. The initial soil (0$15 \mathrm{~cm}$ depth) test result showed that the soil contained $0.058 \%$ total $\mathrm{N}, 0.463 \%$ organic matter, $23 \mathrm{ppm}$ available P, 5.0 ppm available S and 0.13 ppm exchangeable $\mathrm{K}$. Three levels of nitrogen $(0,25$ and $40 \mathrm{~kg} \mathrm{~N}$ $\left.\mathrm{ha}^{-1}\right)$ and four levels of phosphorus $\left(0,18,36\right.$ and $\left.54 \mathrm{~kg} \mathrm{P} \mathrm{ha}^{-1}\right)$ were considered as treatment for the experiment. The experiment was laid out in a randomized complete block design with three replications. Urea \& TSP were used as the source of $N \& P$, respectively.

Half of the $\mathrm{N}$ and whole of $\mathrm{P}$ were applied as basal on 5 January 2009 as per treatment in the individual plots. Besides, MoP and gypsum were applied @ 120 and $115 \mathrm{~kg} \mathrm{ha}^{-1}$, respectively on the same date. Inoculum @ $50 \mathrm{~g} \mathrm{~kg}^{-1}$ of seed was mixed with seed prior to sowing. The remaining half of the $\mathrm{N}$ was top dressed at 25 days after sowing. Weeding followed by thinning was done simultaneously twice at 21 and 45 days after sowing. Irrigation was done simultaneously twice on 25 and 55 days after sowing. Sumithion 50 EC @ $3 \mathrm{~m}^{-1}$ and Dimethion $40 \mathrm{EC} @ 2 \mathrm{mLL}^{-1}$ were sprayed to control leaf roller and hairy caterpillar. The crop was harvested on 20 April 2009 at full maturity. The collected data were analyzed statistically following the ANOVA technique and the mean differences were adjudged as per Duncan's Multiple Range Test (Gomez and Gomez, 1984). 


\section{RESULTS AND DISCUSSION}

The results of the present experiment have been presented and discussed in the Table 1, 2 and 3 .

\section{Effect of nitrogen}

Nitrogen had significant effect on yield and yield contributing characters of soybean (Table 1). Plant height was significantly influenced by nitrogen. Crop grown with $40 \mathrm{~kg} \mathrm{~N}^{-1}$ produced the tallest plant $(34.18 \mathrm{~cm})$ and with $0 \mathrm{~kg} \mathrm{~N} \mathrm{ha}^{-1}$ treatment produced the shortest plants $(30.01 \mathrm{~cm})$. The highest dry matter weight plant ${ }^{-1}(17.89 \mathrm{~g})$, number of seeds pod ${ }^{-1}(1.94)$, number of seeds plant ${ }^{-1}$ (94.93), seeds weight plant ${ }^{-1}(3.41 \mathrm{~g}), 1000$ seed weight $(111.26 \mathrm{~g})$, number of filled pods plant ${ }^{-1}$ (47.59) but lowest empty pods plant ${ }^{-1}$ (2.42) were observed with $25 \mathrm{~kg} \mathrm{~N} \mathrm{ha}^{-1}$ followed by $40 \mathrm{~kg} \mathrm{~N}$ $\mathrm{ha}^{-1}$ application whereas, the crops showed poor performance with no nitrogen $\left(0 \mathrm{~kg} \mathrm{~N} \mathrm{ha}{ }^{-1}\right)$ application.


statistically significant than other treatments. The lowest weight of 1000 seed $(111.26 \mathrm{~g})$ was obtained with control treatment and subsequently lowers than others. The present result supports the report of Raju and Verma (1984) as they observed that increased $\mathrm{N}$ fertilizer has an advantageous role on 1000 seed yield increment. The highest seed yield $\left(1.95 \mathrm{t} \mathrm{ha}^{-1}\right)$ was obtained in $25 \mathrm{~kg} \mathrm{~N} \mathrm{ha}^{-1}$ and the lowest (1.41 tha $\left.{ }^{-1}\right)$ was recorded in control $\left(0 \mathrm{~kg} \mathrm{~N} \mathrm{ha}^{-1}\right)$ treatment. The highest seed yield in $25 \mathrm{~kg} \mathrm{~N} \mathrm{ha}^{-1} \mathrm{might}$ have resulted due to cumulative favourable effects of number of seeds plant ${ }^{-1}$, weight of seeds plant ${ }^{-1}$ and 1000 seed weight. The result obtained is in agreement with the findings of Singh et al. (1992) as he reported yield of soybean increased with the increased rate of $\mathrm{N}$ fertilizer rate. The stover yield followed the similar trend as observed for seed yield. Leelavathi et al. (1991) obtained the similar findings in case of stover yield.

\section{Effect of phosphorus}

Phosphorus had tremendous effect on soybean (Table 2). The yield and yield contributing characters showed better response with the increased level of phosphorus. The tallest plant $(34.26 \mathrm{~cm})$, maximum dry matter weight plant ${ }^{-1}(18.89 \mathrm{~g})$ and maximum number of branches plant ${ }^{-1}(3.37)$ was recorded with $54 \mathrm{~kg}$ $\mathrm{P}$ ha ${ }^{-1}$ which was significantly highest than those of other treatments. The number of filled pods plant ${ }^{-1}(54.49)$ was the highest in $54 \mathrm{~kg} \mathrm{P} \mathrm{ha}^{-1}$ which was significantly highest than those of other treatments. The lowest number of filled pods plant ${ }^{-1}$ was observed from $0 \mathrm{~kg} \mathrm{P} \mathrm{ha}^{-1}$. The present results supports the reports of Singh and Bajpai (1990) who observed that increasing phosphorus rate increased the number of pods plant $^{-1}$. Among the treatments $0 \mathrm{~kg} \mathrm{P} \mathrm{ha}^{-1}$ produced the highest number of empty pods (3.98) which was statistically significant with other treatments and the lowest (2.16) was found in $54 \mathrm{~kg} \mathrm{P} \mathrm{ha}^{-1}$. Islam et al. (2004) reported that the percentage of empty pods decreased with the increase of phosphorus application. Number of seeds pod ${ }^{-1}$ was escalated with the increased dose of phosphorus. Tomar et al. (2004) observed that number of seeds pod $^{-1}$ increased with the increase of phosphorus application. Similar trend was found in case of seeds plant ${ }^{-1}$. The obtained result is in agreement with the findings of Islam et al. (2004). Maximum weight of seed plant ${ }^{-1}(3.49 \mathrm{~g})$ was observed in $54 \mathrm{~kg} \mathrm{P} \mathrm{ha}^{-1}$. The highest weight of stover plant ${ }^{-1}$ $(9.07 \mathrm{~g})$ and 1000 -seed weight $(122.2 \mathrm{~g})$ was observed in $54 \mathrm{~kg} \mathrm{P} \mathrm{ha}^{-1}$ which were statistically significant than those of other treatments whereas lowest from control $\left(0 \mathrm{~kg} \mathrm{P} \mathrm{ha}^{-1}\right)$ treatment. Significantly higher seed yield $\left(2.09 \mathrm{t} \mathrm{ha}^{-1}\right)$ was obtained in $54 \mathrm{~kg} \mathrm{P} \mathrm{ha}^{-1}$ and the lower $\left(1.30 \mathrm{t} \mathrm{ha}^{-1}\right)$ was recorded in control $(0 \mathrm{~kg}$ $\mathrm{P}$ ha-1). The highest seed yield in $54 \mathrm{~kg} \mathrm{P}^{-1}$ might have resulted due to cumulative effects of the number of seeds pod $^{-1}$, number of seed plant ${ }^{-1}$ and weight of seeds plant ${ }^{-1}$. The present results support the reports of Syafruddin et al. (1990) who observed that seed yield was highest $90 \mathrm{~kg} P$ $\mathrm{ha}^{-1}$. The stover yield followed the similar trend as observed in seed yield. Tomar et al. (2004) reported higher trend of stover yield with higher dose of $P$ fertilizer. 
Table 1. Effect of nitrogen on the yield and related crop characters of soybean var. Shohag

\begin{tabular}{|c|c|c|c|c|c|c|c|c|c|c|c|c|c|}
\hline $\begin{array}{l}\text { Level of } \\
\text { nitrogen } \\
\left(\mathrm{kg} \mathrm{N} \mathrm{ha}^{-1}\right)\end{array}$ & $\begin{array}{l}\text { Plant } \\
\text { Height } \\
\text { (cm) }\end{array}$ & $\begin{array}{l}\text { Dry } \\
\text { matter } \\
\text { plant }^{-1} \\
\text { (g) } \\
\end{array}$ & $\begin{array}{l}\text { No. of } \\
\text { branches }^{-1} \text { plant }^{-1}\end{array}$ & $\begin{array}{l}\text { No. of } \\
\text { nodes } \\
\text { plant }^{-1}\end{array}$ & $\begin{array}{l}\text { No. of } \\
\text { filled } \\
\text { pods } \\
\text { plant }^{-1} \\
\end{array}$ & $\begin{array}{l}\text { No. of } \\
\text { empty } \\
\text { pods } \\
\text { plant }^{-1} \\
\end{array}$ & $\begin{array}{l}\text { No. of } \\
\text { seeds } \\
\text { pod }^{-1}\end{array}$ & $\begin{array}{l}\text { No. of } \\
\text { seeds } \\
\text { plant }^{-1}\end{array}$ & $\begin{array}{l}\text { Seed wt. } \\
\text { Plant }^{-1} \\
\text { (g) }\end{array}$ & $\begin{array}{l}\text { Stover wt. } \\
\text { Plant }^{-1} \text { (g) }\end{array}$ & $\begin{array}{l}\text { 1000- } \\
\text { seed } \\
\text { wt. (g) }\end{array}$ & $\begin{array}{l}\text { Seed } \\
\text { yield } \\
\left(\mathrm{t} \mathrm{ha}^{-1}\right)\end{array}$ & $\begin{array}{l}\text { Stover } \\
\text { yield } \\
\left.(\mathrm{t} \mathrm{ha})^{-1}\right)\end{array}$ \\
\hline 0 & $30.01 \mathrm{c}$ & $12.89 \mathrm{c}$ & $2.17 b$ & 9.88 & $38.00 \mathrm{c}$ & $3.31 a$ & $1.64 \mathrm{c}$ & $64.98 \mathrm{c}$ & $3.07 b$ & $6.14 \mathrm{c}$ & $111.26 \mathrm{c}$ & $1.41 \mathrm{c}$ & $1.69 c$ \\
\hline 25 & $31.78 \mathrm{~b}$ & $17.89 a$ & $2.73 a$ & 10.29 & $47.59 a$ & $2.42 \mathrm{c}$ & $1.94 a$ & $94.93 a$ & $3.41 a$ & $8.48 a$ & $120.24 a$ & $1.95 \mathrm{a}$ & $2.35 a$ \\
\hline 40 & $34.18 a$ & $17.22 \mathrm{~b}$ & $2.65 a$ & 9.88 & $40.4 b$ & $2.75 b$ & $1.76 \mathrm{~b}$ & $73.20 \mathrm{~b}$ & $2.91 b$ & $8.20 \mathrm{~b}$ & $117.99 b$ & $1.89 \mathrm{~b}$ & $2.25 b$ \\
\hline Sx & 0.35 & 0.11 & 0.05 & 0.34 & 0.65 & 0.06 & 0.03 & 1.75 & 0.11 & 0.07 & 0.55 & 0.02 & 0.02 \\
\hline $\begin{array}{c}\text { Level of } \\
\text { significance }\end{array}$ & ** & ** & $\star *$ & NS & ** & ** & ** & $\star \star$ & ** & ** & ** & ** & $\star *$ \\
\hline
\end{tabular}

In a column figures with same letter or without letter do not differ significantly whereas figures with dissimilar letter differ significantly (as per DMRT)

$\mathrm{Sx}=$ Sample standard deviation; ${ }^{*}=$ Indicates significant at $5 \%$ level of probability; ${ }^{\star}=$ Indicates significant at $1 \%$ level of probability; NS = Indicates not significant 
Table 2. Effect of phosphorus on the yield and related crop characters of soybean var. Shohag

\begin{tabular}{|c|c|c|c|c|c|c|c|c|c|c|c|c|c|}
\hline $\begin{array}{l}\text { Level of } \\
\text { nitrogen } \\
\left(\mathrm{kg} \mathrm{P} \mathrm{ha}^{-1}\right)\end{array}$ & $\begin{array}{l}\text { Plant } \\
\text { Height } \\
\text { (cm) }\end{array}$ & $\begin{array}{l}\text { Dry } \\
\text { matter } \\
\text { plant }^{-1}(g)\end{array}$ & $\begin{array}{l}\text { No. of } \\
\text { branches } \\
\text { plant }^{-1}\end{array}$ & $\begin{array}{l}\text { No. of } \\
\text { nodes } \\
\text { plant }^{-1}\end{array}$ & $\begin{array}{l}\text { No. of } \\
\text { filled pods } \\
\text { plant }^{-1}\end{array}$ & $\begin{array}{l}\text { No. of } \\
\text { empty } \\
\text { pods plant }{ }^{-1}\end{array}$ & $\begin{array}{l}\text { No. of } \\
\text { seeds } \\
\text { pod }^{-1}\end{array}$ & $\begin{array}{l}\text { No. of } \\
\text { seeds } \\
\text { plant }^{-1}\end{array}$ & $\begin{array}{l}\text { Seed wt. } \\
\text { Plant }^{-1} \\
\text { (g) }\end{array}$ & $\begin{array}{l}\text { Stover wt. } \\
\text { Plant }^{-1}(\mathrm{~g})\end{array}$ & $\begin{array}{l}\text { 1000- } \\
\text { seed } \\
\text { wt. (g) }\end{array}$ & $\begin{array}{l}\text { Seed } \\
\text { yield } \\
\left(\mathrm{t} \mathrm{ha}^{-1}\right)\end{array}$ & $\begin{array}{l}\text { Stovel } \\
\text { yield } \\
\left(\mathrm{t} \mathrm{ha}^{-1}\right)\end{array}$ \\
\hline 0 & $30.95 b$ & $12.12 d$ & $1.85 d$ & 9.58 & $29.77 d$ & $3.98 a$ & $1.27 \mathrm{c}$ & $38.07 d$ & $3.03 b$ & $5.67 d$ & $109.15 d$ & $1.30 \mathrm{~d}$ & $1.61 d$ \\
\hline 18 & $31.3 b$ & $16.17 \mathrm{c}$ & $2.09 c$ & 10.00 & $38.98 \mathrm{c}$ & $2.67 b$ & $1.87 \mathrm{~b}$ & $73.31 \mathrm{c}$ & $3.13 a b$ & $7.71 \mathrm{c}$ & $115.06 \mathrm{c}$ & $1.77 \mathrm{c}$ & $2.11 \mathrm{c}$ \\
\hline 36 & $31.46 \mathrm{~b}$ & $16.83 b$ & $2.75 b$ & 10.19 & $44.74 b$ & $2.50 \mathrm{~b}$ & $1.91 b$ & $85.95 b$ & $2.86 \mathrm{~b}$ & $7.99 b$ & $119.58 b$ & $1.84 b$ & $2.21 b$ \\
\hline 54 & $34.26 a$ & $18.89 a$ & $3.37 a$ & 10.31 & $54.49 a$ & $2.16 c$ & $2.07 a$ & $113.48 a$ & $3.49 a$ & $9.07 a$ & $122.2 \mathrm{a}$ & $2.09 a$ & $2.46 a$ \\
\hline Sx & 0.4 & 0.13 & 0.06 & 0.39 & 0.75 & 0.07 & 0.03 & 2.02 & 0.12 & 0.09 & 0.63 & 0.02 & 0.02 \\
\hline $\begin{array}{l}\text { Level of } \\
\text { significance }\end{array}$ & ** & $\star *$ & ** & NS & ** & $\star \star$ & ** & ** & ** & ** & ** & ** & ** \\
\hline
\end{tabular}

In a column figures with same letter or without letter do not differ significantly whereas figures with dissimilar letter differ significantly (as per DMRT)

Sx = Sample standard deviation; ${ }^{*}=$ Indicates Significant at $5 \%$ level of probability; ${ }^{\star *}=$ Indicates Significant at $1 \%$ level of probability; NS = Indicates Not significant. 
Table 3. Interaction effect of nitrogen and phosphorus on the yield and related crop characters of soybean var. Shohag

\begin{tabular}{|c|c|c|c|c|c|c|c|c|c|c|c|c|c|}
\hline $\begin{array}{l}\text { Level of nitrogen } \\
\text { and phophorus } \\
\mathrm{N} \times \mathrm{P} \\
\left(\mathrm{kg} \mathrm{ha}^{-1}\right)\end{array}$ & $\begin{array}{l}\text { Plant } \\
\text { Height } \\
\text { (cm) }\end{array}$ & $\begin{array}{l}\text { Dry } \\
\text { matter }^{-1} \\
\text { plant }^{-1} \\
\text { (g) } \\
\end{array}$ & $\begin{array}{l}\text { No. of } \\
\text { branches } \\
\text { plant }^{-1}\end{array}$ & $\begin{array}{l}\text { No. of } \\
\text { nodes } \\
\text { plant }^{-1}\end{array}$ & $\begin{array}{l}\text { No. of } \\
\text { filled } \\
\text { pods } \\
\text { plant }^{-1} \\
\end{array}$ & $\begin{array}{l}\text { No. of } \\
\text { empty } \\
\text { pods } \\
\text { plant }^{-1} \\
\end{array}$ & $\begin{array}{l}\text { No. of } \\
\text { seeds } \\
\text { pod }^{-1}\end{array}$ & $\begin{array}{l}\text { No. of } \\
\text { seeds } \\
\text { plant }^{-1}\end{array}$ & $\begin{array}{l}\text { Seed wt. } \\
\text { Plant }^{-1}(g)\end{array}$ & $\begin{array}{l}\text { Stover } \\
\text { wt. } \\
\text { Plant }^{-1} \\
\text { (g) } \\
\end{array}$ & $\begin{array}{l}1000- \\
\text { seed } \\
\text { wt. (g) }\end{array}$ & $\begin{array}{l}\text { Seed } \\
\text { yield } \\
\left(\mathrm{t} \text { ha }^{-1}\right)\end{array}$ & $\begin{array}{l}\text { Stover } \\
\text { yield } \\
\left.\text { (t ha }^{-1}\right)\end{array}$ \\
\hline $0 \times 0$ & 31.73de & $9.82 \mathrm{j}$ & $1.63 \mathrm{fg}$ & 9.27 & $23.5 \mathrm{~h}$ & $4.08 a$ & 1.25 & $29.36 \mathrm{i}$ & $3.56 a b c$ & $4.69 \mathrm{~h}$ & $105.13 \mathrm{e}$ & $1.08 \mathrm{i}$ & $1.28 \mathrm{~h}$ \\
\hline $0 \times 18$ & $29.02 \mathrm{fg}$ & $11.79 \mathrm{~h}$ & $1.43 \mathrm{~g}$ & 10.00 & $36.48 \mathrm{ef}$ & $3.24 b$ & 1.63 & $59.62 \mathrm{~g}$ & $2.49 \mathrm{ef}$ & $5.77 f$ & $111.23 d$ & $1.33 \mathrm{~g}$ & $1.50 \mathrm{~g}$ \\
\hline $0 \times 36$ & $27.77 \mathrm{~g}$ & $13.28 \mathrm{~g}$ & $2.73 b c$ & 9.87 & $39.86 \mathrm{de}$ & $3.12 b c$ & 1.78 & 70.94ef & 2.64def & $6.18 f$ & $114.47 d$ & $1.42 f$ & $1.77 f$ \\
\hline $0 \times 54$ & 31.53de & $16.69 \mathrm{e}$ & $2.87 b$ & 10.40 & $52.14 b$ & $2.78 \mathrm{~cd}$ & 1.92 & $100.01 \mathrm{c}$ & $3.60 \mathrm{abc}$ & $7.94 d$ & $114.20 d$ & $1.83 d$ & $2.19 d$ \\
\hline $25 \times 0$ & 31.22def & $15.48 f$ & $2.03 e$ & 9.20 & $35.41 f$ & $3.85 a$ & 1.41 & $50.11 \mathrm{~h}$ & $2.30 f$ & $5.12 \mathrm{~g}$ & $107.60 \mathrm{e}$ & $1.66 \mathrm{e}$ & $2.07 e$ \\
\hline $25 \times 18$ & $33.15 \mathrm{~cd}$ & $16.69 \mathrm{e}$ & $2.48 \mathrm{~cd}$ & 10.07 & $44.33 c$ & $2.20 \mathrm{ef}$ & 1.98 & $87.98 d$ & 3.15b-e & $9.49 b$ & $114.27 d$ & $1.81 \mathrm{~d}$ & $2.21 d$ \\
\hline $25 \times 36$ & $35.48 a b$ & $17.55 d$ & $2.70 \mathrm{bc}$ & 10.83 & $52.34 b$ & $2.00 f$ & 2.05 & $107.15 b$ & 3.20a-e & $9.30 \mathrm{~b}$ & $122.10 \mathrm{bc}$ & $1.95 \mathrm{c}$ & $2.26 \mathrm{~d}$ \\
\hline $25 \times 54$ & $36.88 a$ & $20.81 a$ & $3.71 a$ & 11.07 & $58.28 a$ & $1.63 \mathrm{~g}$ & 2.31 & $134.48 \mathrm{a}$ & $3.89 a$ & $10.01 a$ & $127.98 a$ & $2.30 a$ & $2.63 a$ \\
\hline $40 \times 0$ & 30.95def & $11.07 i$ & $1.88 \mathrm{ef}$ & 10.27 & $30.41 \mathrm{~g}$ & $4.01 a$ & 1.14 & 34.75hi & 3.23a-d & $7.20 \mathrm{e}$ & $114.73 d$ & $1.18 \mathrm{~h}$ & $1.49 \mathrm{~g}$ \\
\hline $40 \times 18$ & 30.68 ef & $20.02 b$ & $2.34 d$ & 9.93 & $36.14 \mathrm{ef}$ & $2.56 \mathrm{de}$ & 2.00 & $72.34 \mathrm{e}$ & $3.77 a b$ & $7.86 \mathrm{~d}$ & 119.67c & $2.13 b$ & $2.48 \mathrm{c}$ \\
\hline $40 \times 36$ & 31.13def & $19.66 \mathrm{bc}$ & $2.83 b$ & 9.87 & $42.01 \mathrm{~cd}$ & $2.37 \mathrm{ef}$ & $1.9 \mathrm{~b}$ & 79.76de & $2.75 \mathrm{def}$ & $8.49 c$ & $122.16 b c$ & $2.14 b$ & $2.59 \mathrm{~b}$ \\
\hline $40 \times 54$ & $34.36 \mathrm{bc}$ & $19.18 \mathrm{c}$ & $3.55 a$ & 9.47 & $53.05 b$ & $2.07 f$ & 2.00 & $105.94 b c$ & $2.98 \mathrm{c}-\mathrm{f}$ & $9.26 \mathrm{~b}$ & $124.41 b$ & $2.18 a$ & $2.70 \mathrm{a}$ \\
\hline Sx & 0.69 & 0.22 & 0.10 & 0.68 & 1.3 & 0.12 & 0.06 & 3.49 & 0.22 & 0.15 & 1.09 & 0.03 & 0.03 \\
\hline $\begin{array}{l}\text { Level of } \\
\text { significance }\end{array}$ & $\star \star$ & ** & ** & NS & $\star \star$ & $\star \star$ & NS & * & ** & * & $\star \star$ & $\star \star$ & ** \\
\hline
\end{tabular}

In a column figures with same letter or without letter do not differ significantly whereas figures with dissimilar letter differ significantly (as per DMRT)

$\mathrm{Sx}=$ Sample standard deviation; * = Indicates significant at $5 \%$ level of probability; ${ }^{\star *}=$ Indicates significant at $1 \%$ level of probability; NS = Indicates not significant. 


\section{Effect of interaction of nitrogen and phosphorus}

The interaction effect of nitrogen and phosphorus on plant height has been shown in table 3 . It is evident from the results that there was no regular trend in plant height due to interaction of $\mathrm{N}$ and $\mathrm{P}$. The highest plant height $(36.88 \mathrm{~cm})$ was obtained from the highest level of $\mathrm{N}$ and $\mathrm{P}$. Whereas, the lowest plant height $(27.77$ $\mathrm{cm}$ ) was obtained from the combination of $0 \mathrm{~kg} \mathrm{~N}$ with $36 \mathrm{~kg} \mathrm{P} \mathrm{ha}^{-1}$. The highest dry weight of plant (20.81 g) was obtained from the highest level of nitrogen and phosphorus ( $25 \mathrm{~kg} \mathrm{~N}$ with $\left.54 \mathrm{~kg} \mathrm{P}^{-1}\right)$. Whereas the lowest dry weight of plant $(9.82 \mathrm{~g})$ was obtained from the combination of $0 \mathrm{~kg} \mathrm{~N}$ with $0 \mathrm{~kg} \mathrm{P}^{-1}$. It is evident from the results that there was no regular trend in number of branches plant ${ }^{-1}$ and number of filled pods plant ${ }^{-1}$ due to interaction of $\mathrm{N}$ and $\mathrm{P}$. There is a tendency of producing less number of empty pods plant ${ }^{-1}$ due to the effect of interaction of highest levels of phosphorus irrespective of nitrogen. The highest empty pods plant ${ }^{-1}$ (4.08) was recorded from the $0 \mathrm{~kg} \mathrm{~N}$ with $0 \mathrm{~kg} \mathrm{P}^{-1}$ which was statistically significant with the $25 \mathrm{~kg} \mathrm{~N}$ with $0 \mathrm{~kg} \mathrm{P} \mathrm{ha}^{-1}$ and $40 \mathrm{~kg} \mathrm{~N}$ with $0 \mathrm{~kg} \mathrm{P} \mathrm{ha}^{-1}$. The lowest number of empty pods plant ${ }^{-1}$ (1.63) was obtained from $25 \mathrm{~kg} \mathrm{~N}$ with $54 \mathrm{~kg} \mathrm{P} \mathrm{ha}^{-1}$. The number of seeds pod $^{-1}$ due to interaction effect of nitrogen and phosphorus was statistically insignificant. The maximum (134.48) seeds plant ${ }^{-1}$ was observed in $25 \mathrm{~kg} \mathrm{~N}$ with $54 \mathrm{~kg} \mathrm{P}^{-1}$ and the minimum (29.36) was observed from $25 \mathrm{~kg} \mathrm{~N}$ with $54 \mathrm{~kg} \mathrm{P} \mathrm{ha}^{1}$. Almost similar trend in the effect of interaction of $\mathrm{N}$ and $\mathrm{P}$ was observed on weight of seeds plant ${ }^{-1}$ as it was exhibited on plant height, number of filled pods plant ${ }^{-1}$, number of seeds plant ${ }^{-1}$. Here also the highest weight of seeds plant ${ }^{-1}(3.89 \mathrm{~g})$, weight of stover plant ${ }^{-1}(10.01 \mathrm{~g})$ was obtained from $25 \mathrm{~kg} \mathrm{~N}$ with $54 \mathrm{~kg} \mathrm{P}$ $\mathrm{ha}^{-1}$ and lowest $(4.69 \mathrm{~g})$ from the $0 \mathrm{~kg} \mathrm{~N}$ with $0 \mathrm{~kg} \mathrm{P} \mathrm{ha}^{-1}$. The effect of interaction of nitrogen and phosphorus on 1000-seed weight was statistically significant. Almost the similar trend in the effect of interaction of $\mathrm{N}$ and $\mathrm{P}$ was observed on seed yield as it was exhibited on dry weight of plant, number of filled pods plant ${ }^{-1}$, number of seeds plant ${ }^{-1}$, and weight of seeds plant ${ }^{-1}$ and the weight of stover plant ${ }^{-1}$. The treatment combination of $25 \mathrm{~kg} \mathrm{~N}$ with $54 \mathrm{~kg} \mathrm{P}^{-1}$ hroduced the highest seed yield $\left(2.30 \mathrm{t} \mathrm{ha}^{-1}\right)$, which was similar with $40 \mathrm{~kg} \mathrm{~N}$ with $54 \mathrm{~kg} \mathrm{P} \mathrm{ha}^{-1}$ and significantly highest than those of other treatments. On the other hand $0 \mathrm{~kg} \mathrm{~N}$ with $0 \mathrm{~kg} \mathrm{P} \mathrm{ha-1}$ produced the lowest $\left(1.08 \mathrm{t} \mathrm{ha}^{-1}\right)$ seed yield. Stover yield varied significantly due to interaction of nitrogen and phosphorus. The results indicated that higher stover yield in soybean could be obtained by $40 \mathrm{~kg} \mathrm{~N}$ with $54 \mathrm{~kg} \mathrm{P}^{\mathrm{P}} \mathrm{h}^{-1}$.

\section{CONCLUSION}

The results, therefore, indicated that nitrogen and phosphorus had significant effect on yield performance of soybean including other yield contributing parameters as well as suggested that the combined application of nitrogen and phosphorus @ $25 \mathrm{~kg} \mathrm{~N}$ with $54 \mathrm{~kg} \mathrm{P} \mathrm{ha}^{-1}$ might produce the best seed yield in soybean var. Shohag.

\section{REFERENCES}

1. BARI (Bangladesh Agricultural Research Institute) 2005. Handbook on Agro-technology. $2^{\text {nd }}$ Edition, BARI, Gazipur. p. 155.

2. FAO (Food and Agriculture Organization). 2008. FAO Yearbook Production. Food and Agricultural Organization of the United Nations Rome. 57: 115.

3. Gomez, KA and AA Gomez 1984. Statistical Procedure for Agricultural Research. $2^{\text {nd }}$ edition, International Rice Research Institute. John Wiley and Sons, Inc, Singapore. pp. 139-240.

4. Islam MK, MAA Mondal, MA Mannaf, MAA Mondal, MAH Talukder and MM Karim, 2004. Effects of variety, inoculum and phosphorus on the performance of soybean. Agricultural Research Station, Debigonj, Panchagar, Bangladesh. Pakistan Journal of Biological Science, 7: 2072-2077.

5. Leelavathi GSNS, GV Subbaiah and RN Pillai, 1991. Effect of different levels of nitrogen on the yield of mungbean (Vigna rakiata L. Wilczek). Andhra Agriculture Journal, 38: 93-94.

6. Mandal MR and MA Wahhab, 2001. Production Technology of Oil crops. Oilseed Research Centre, Bangladesh Agricultural Research Institute, Joydevpur, Gazipur. pp. 1-10.

7. Rahman L, 1982. Cultivation of Soybean and Its Uses. City press. Dhaka. pp. 5-7. 
8. Raju MS and SC Varma, 1984. Response of mungbean (Vigna radiata) to Rhizobial inoculation in relation to fertilizer nitrogen. Legume Research 7: 73-76.

9. Rao AS, DD Reddy and PN Takkar, 1995. Phosphorus management-A key to boost productivity of soybean-wheat cropping system on swell-shrink soils. Fertilizer. News. 40: 87-95.

10. Singh HN, FW Prasad and JK Varshney, 1992. Effect of nitrogen and row spacing on nodulation, growth and yield of soybean (Glycine max L. Merr) var. Gaurav. New Agriculturist. 3: 31-34.

11. Singh VK and RP Bajpai, 1990. Effect of phosphorus and potash on the growth and yield of rainfed soybean. Indain Journal of Agronomy, 35: 310-311.

12. Steward WDP, 1966. Nitrogen fixation in plants Alhloe Press, University of London. P. 130.

13. Syafruddin RM, S Saenong and D Jamaluddin, 1990. Response of soybeans (Glycine max L. Merrill) to $P$ and Zn application in calcareous alluvial soil. Soybean Abstract, 1992. 15: 220.

14. Tomar SS, R Singh and SP Singh, 2004. Response of phosphorus, sulphur and rhizobium inoculation on growth, yield and quality of soybean (Glycine max. L.). Progressive Agriculture, 4: 72-73.

15. USDA, 2009. Nutrient Database for Standard Reference Release 27 (Soybean). ndb.nal.usda.gov/ndb/ 